Revised Abstract for

Article Title: John Falk and Lynn Dierking: building the field of informal/free-choice science education DOI: 10.1007/s11422-015-9707-3

CSSE_KEY CONTRIBUTORS_John and Lynn

This article establishes the importance of "context", a concept that underpins the academic contributions that John Falk and Lynn Dierking have made in building the field of informal/free-choice learning in science education. I consider, in turn, the individual contributions made by each of them prior to their seminal coauthored work, entitled "The Museum Experience." I then document their joint contributions to the field, pointing out that although their interests and skills overlap in complementary ways to produce their jointly authored works, both have continued to make their individual contributions; Falk in his work on identity and impact, and Dierking in her work on community, youth, family and equity. Finally I come to the present, describing how they each continue their research and publication in lifelong, life-wide, and life-deep learning, with a particular focus on free-choice learning and the role it can play in addressing critical issues in the world. 


\section{John H. Falk and Lynn D. Dierking: Building the Field of Informal/Free-Choice Science Education}

\section{Léonie J. Rennie}

Keywords free-choice informal science education life-long learning

In November 1997, I was preparing for a brief visit to Washington DC and thought it would be a great opportunity to visit the Institute for Learning Innovation, often called "ILI" by those in the field, in nearby Annapolis, Maryland. I emailed John Falk and Lynn Dierking (Director and Associate Director, respectively), and they generously invited me to offer a seminar there. Lynn sent instructions for the train journey, but having never been to Washington Union Station, I was a bit confused by information about signage to platforms and asked for clarity. "Don't worry" replied Lynn, "you'll understand when you get there. Context is everything!" And, I discovered, it was. My journey was completed without incident.

Context is a theme that both unites and underpins a truly remarkable body of work by John Falk and Lynn Dierking, the two researchers who have done most to illuminate our understanding of life-long learning in science. The importance of context will unfold throughout this article, but first it is appropriate to introduce John and Lynn separately, to provide the foundations for their separate and joint contributions to the field of science education.

\section{John H. Falk}

John Howard Falk completed his bachelor and master's degrees in zoology at the University of California, Berkeley, and his interest in out-of-school, lifelong learning, initially focused on outdoor education, soon found him leading tours for visitors to the University's Botanical Garden. John's first article (Falk 1971) was published even before he was awarded his master's degree. However, the paper that more clearly demonstrates John's future trajectory appeared in 1974: "Estimating experimenter induced bias in field studies: A cautionary tale," in Oikos, an international peer-reviewed journal focused on ecology. This paper challenged the assumption that biologists in general, and ecologists in particular, could ignore the impact they have as experimenters/researchers on the systems they study. The prevailing assumption at the time, and 
by and large still today, was that as long as an investigator made an effort to be careful and tried to "tread lightly" on the system s/he was studying s/he was justified in totally ignoring any distorting impact s//he might have on that system through its study. The Oikos paper demonstrated that this was not true and that not only did investigators regularly influence the systems they studied, it was possible both theoretically and practically, to quantitatively measure the impact. This paper, written by John while still a graduate student, represents an early example of Falk's lifelong effort to step outside of everyday practice, to view not only his own practice, but that of others as well, from a sufficiently "critical distance" to ascertain the potential distortions that practice, in this case research, may be creating. It also demonstrated his ability to develop new methods and approaches in an attempt to better capture the context and reality of a situation.

It was through Berkeley's Botanical Garden that John met Watson M. (Mac) Laetsch, then Professor of Botany and Director of the Garden; he was also the soon-to-be Director of the Lawrence Hall of Science (LHS). Mac Laetsch explained that John

subsequently entered the Graduate Group in Science and Mathematics Education (SESAME), an interdisciplinary $\mathrm{PhD}$ program in Science and Mathematics Education; and I became his thesis advisor. A large NSF-funded Program at LHS called "Outdoor Biology-Instructional Strategies" (OBIS) was getting started, and John joined the staff. His PhD thesis concerned the biology of urban lawns, one of the most common ecosystems worldwide, but John's work to study it from a biological perspective and to use the knowledge for broad educational purposes was pioneering. OBIS is an international program, and John's lawn activities have literally gone around the world. (Mac Laetsch, personal communication, February 25, 2014)

In completing his doctorate in 1974, John conducted two separate but inter-related dissertations; one on the ecology of a suburban lawn and the other on how to use lawns and schoolyards to teach ecology to children. His year-long scientific ecological study of a lawn from an energetics perspective (see Falk 1976) is inspirational in the intensity of observation, the attention to detail, and the meticulous, innovative data collection and analysis he utilized. This work foreshadowed the depth of thought and creativity with which his subsequent research 
activities are conducted. The educational part of John's dissertation concerned out-of-school learning; how lawns and schoolyards could be used by youth groups to learn about nature, thus making a major contribution to OBIS. Mac Laetsch elaborated on the out-of-school perspective in OBIS:

OBIS was what we called "informal education" to distinguish it from "formal" or school based education. John prefers the term "free choice education" and he has devoted his career to its study. He has emphasized that most people have science related experience throughout their lives and in many different venues. He has shown that many adults in the US know more about science than adults in other countries where school students score higher on standardized tests. This should be required knowledge for educators. (Mac Laetsch, personal communication, February 25, 2014)

After completing his doctorate John moved across the country and in 1974 he founded the Educational Research program at the Smithsonian's Chesapeake Bay Center for Environmental Research. His first NSF grant, in 1976, was an extension of the OBIS project. This was possibly the first NSF research grant awarded that focused on learning outside of the classroom, specifically on learning during school field trips. In 1983 he established and directed the Smithsonian Office of Educational Research. John continued to publish about field trips, including the findings of significant research about the implications of context (e.g., Falk \& Balling 1982) and effect of novelty (e.g., Falk Martin \& Balling, 1978) on learning, and the relationships between time and behavior as predictors of learning in museums (Falk 1983). With roots still in educational practice, as well as research, he also created the Smithsonian Family Learning Project, affectionately referred to as SFLP, which resulted in a series of calendars and books that families could use at home to engage with science. Unfortunately, a new incoming Smithsonian Secretary who saw no reason to conduct research or develop materials supporting learning outside of school abolished the office.

In 1986, John founded the Institute for Learning Innovation and became its inaugural Director. Based in Annapolis, MD, it was a not-for-profit research and development organization focused on understanding and supporting free-choice learning. John and the Institute staff were 
able to concentrate on free-choice learning research in many settings, ensuring that research and evaluation in this field became well-established.

\section{Lynn D. Dierking}

Lynn Diane Dierking's first degree was in biology at the University of Miami; she then moved to the University of Florida to complete her master's and doctorate in science education, focusing

on learning in museums. During much of this time, Lynn was a museum educator and classroom science teacher, so science education in places like museums was an ideal research choice. Lynn's first publication (as Lynn Dierking-Shafer) with the late John J. Koran, Jr., her major advisor, was entitled "Learning Science in Informal Settings outside the Classroom," in a National Education Association publication edited by Mary Budd Rowe (Koran and DierkingShafer 1982). The authors argued for a closer relationship between schools and learning opportunities outside of them, but cautioned against "transforming an informal experience into a formal school experience with at least some of the negative connotations" (p. 62). They discussed the need to understand the factors that "bring out the curiosity and spirit of discovery" of informal science, concluding "that is the challenge informal education presents to us in the decade of the $80 \mathrm{~s}$ " (p. 62). It is a challenge still inadequately responded to. Although this early publication was designed to serve as a resource for teachers, it included the important observation that "Museums and zoos provide a wonderful setting for families to share science" (p. 61). This would be a prescient statement given that Lynn would focus on this arena of research for a good part of her scholarly career.

A further contribution to science education was "A Framework for Conceptualizing Research in Natural History Museums and Science Centers" (Koran, Longino, and Shafer 1983), published in the Journal of Research in Science Teaching. This article presented an excellent synthesis of research in the field, suggested a classification of exhibits, from static to dynamic, and proposed a conceptual model to guide future research. The conclusion reflected the authors' view that science education needs to include all of these sources of learning.

All indications lead to the inescapable conclusion that the time is here for science educators to expand their research, development, and training activities into museums and science centers and other informal learning settings around 
the country. This article was designed to provide a jumping-off place to avoid the inevitable lag time which occurs as researchers in different parts of the country vigorously work to reinvent the wheel. (p. 366)

In 1984 Lynn moved to the Smithsonian Office of Educational Research to coordinate a community science project, while continuing to work on her dissertation and publish with Koran and his team. "Predicting Visitor Behavior" (Falk, Koran, Dierking and Dreblow 1985), published in Curator, pointed out that "museums come face to face with the realities of 'free choice' learning. These realities ensure that predicting what and how visitors learn - let alone if they learn - will be very difficult" (p. 249). This article provided evidence that visitors behave in predictable ways, and that the better these were understood, the more effective museum professionals could make the visitor experience. The first author was John Falk, who had been a visiting professor at University of Florida (UF) in 1983. Soon another significant paper appeared in Science Education, "The Things of Science: Assessing the Learning Potential of Science Museums" (Falk, Koran and Dierking 1986), this time informing science educators of the kinds of learning opportunities offered by museums compared to schools (building on the Koran and Dierking-Shafer 1982 chapter, that was likely the first time these comparisons were made) and, as the title indicates, describing the learning potential of these places. The importance of free choice was discussed in these articles, partly to compare learning opportunities in museums and schools, and partly to explain how difficult it is to ascribe learning to any specific event or experience and, in research terms, to find out what visitors actually learn.

One of Lynn's enduring interests is in family learning and her dissertation, completed in 1987, focused on parent-child interactions (Parent-Child Interactions in a Free Choice Learning Setting: An Examination of Attention-Directing Behaviors). This study built on earlier research by Judy Diamond and Sherman Rosenfeld, working with Mac Laetsch at the Lawrence Hall of Science. By following families from the moment they entered the museum to the moment they left (an idea contributed by John Falk when he was a UF visiting professor), she was able to conduct a "naturalistic" study of families in museums, describing and analyzing the rich and sometimes challenging interactions engaged in by families visiting museums. This work provided both a theoretical and empirical foundation for subsequent research in this arena. 
In 1988 Lynn became a tenure-track faculty member in science education at the University of Maryland. Unfortunately, the timing was not right for developing, let alone sustaining, a research program in free-choice learning, a very emergent discipline twenty-five+ years ago. Lynn returned to the Smithsonian in 1991 to direct the Science in American Life curriculum project at the National Museum of American History, a role in which she led an integrated middle school science and social studies effort. The irony was not lost on her.

In 1993, she joined the Institute as Associate Director and the Falk-Dierking collaboration, already well-established through journal publications and their first jointly authored book, The Museum Experience (Falk \& Dierking 1992), continued to flourish. This collaboration was built on the recognition of the importance of context as a mediator of learning, and the complementarity of John and Lynn's different interests, experiences, and perspectives about learning, particularly free-choice, life-long science learning.

\section{The importance of context in learning}

The Museum Experience (Falk and Dierking 1992) described the critical role that context plays in learning, particularly learning in and from museums. It was a notable milestone in understanding museum learning and research and has justifiably received considerable recognition. Per-Edvin Persson, recently retired Director of Heureka, The Finnish Science Centre, former Director of the Federation of Finnish Scientific Societies (1987 - 1991) and President of the Association of Science-Technology Centers (ASTC, in 2004-2005), recalled

I am happy that one of the early books I had a chance to read as a Director was "The Museum Experience" written by John and Lynn and published back in 1992. I devoured it hot off the press and it changed my view on the museum and science center field completely: I realized that the restrooms, the parking, and the restaurant probably were more important from the visitor's point of view than the scholarly content of the exhibitions. And that we needed to put the visitor in the center of our thoughts. A long way to walk for a person with a solid scientific background! (Per-Edvin Persson, personal communication, March 22, 2014)

Indeed, when The Museum Experience was reprinted in 2011, reviewers wrote 
I was amazed at how well [The Museum Experience] held up over 20 years and how many insights I relearned. ... I think it's still an essential text for the field and one that many people could learn a lot from in [its] present form in 2011. (Nina Simon, Museum 2.0; http://www.lcoastpress.com/book.php?id=348)

I love this book! I still think it is one of the most read-able and applicable books in our field. It is perfect for students or professionals, particularly those who are new to the visitor perspective. (Kris Morrissey, Director, Museology Graduate Program, University of Washington; http://www.lcoastpress.com/book.php?id=348)

In the introduction to The Museum Experience, John and Lynn made the importance of context explicit by proposing a framework of three contexts - the personal, social, and physical contexts - as interacting components in which the experience of visitors to museums and similar places is imbedded. Originally termed The Interactive Experience Model, John and Lynn offered this framework as a tool to organize and interpret the findings of research about the visitor's experience. Eight years later, in Learning from Museums: Visitor Experiences and the Making of Meaning (Falk and Dierking 2000), they built upon and extended the Interactive Experience Model in two significant ways: First, the framework became much more focused on learning, rather than just the experience had by visitors, and second, the dimension of time was included, making explicit the notion that learning is a cumulative process. They re-named this expanded model the Contextual Model of Learning, focusing attention on the key interactions of three psycho-social contexts; the personal, the sociocultural, and the physical. To emphasize the everchanging nature of contexts and learning, as people make meaning from their experiences, Falk and Dierking (2000) wrote:

Learning can be viewed as the never-ending integration and interaction of these three contexts over time in order to make meaning. Perhaps the best way to think of it is to view the personal context as moving through time; as it travels, it is constantly reshaped as it experiences events within the physical context, all of which are mediated by and through the sociocultural context. (p. 11) 
Each of the three contexts is discussed fully in this book, providing thorough coverage of the network of variables that combine to influence the impact of a visit to a free-choice setting (see Falk and Storksdieck 2005, for an example of its use).The significance of the Contextual Model of Learning is difficult to understate, because the framework provides a structure to ensure that all relevant factors are accounted for in planning research, and it also furnishes a means of organizing and analyzing data, as well as reporting the findings. Tali Tal, Associate Professor at Technion, Israel, recalled how she:

began studying students in museums only in the early 2000s right after the Contextual Model of Learning was offered (Falk and Dierking 2000). This highly influential publication helped me a lot in framing my understandings of learning in museums. Moreover, this seminal work has shown me that there is still a lot to do in the area where schools and museums meet. In a way, I realized that the bigger body of research was done on voluntary visits in museums, and that this literature does not always inform research on school visits to museums. One example of how we struggled with the idea of freechoice learning, is in our work on school visits to four museums (Bamberger and Tal 2007), in which we argued that both free choice learning and nonchoice learning have yielded lesser evidence for learning than what we termed limited-choice learning, which is a school visit to a museum that offers some structure in few possible ways. Moreover, in that study, we followed Falk and Dierking's work on long term impacts and were able to show as well that long after the museum visit, some learning outcomes are sustained, especially the social learning outcomes and the motivational ones. These were stronger than the conceptual ones after 16 months. Building on the previous work of Lynn Dierking and John Falk and negotiating with Lynn over the years was great inspiration. (Tali Tal, personal communication, October 1, 2014)

The Museum Experience (Falk and Dierking 1992) was first written in 1986, but it took five years to find a publisher. At that time, John and Lynn found it challenging to unearth other shreds of research evidence to add to their own already significant work. Twenty years later, when compiling The Museum Experience Revisited (Falk and Dierking 2013), the problem was 
more one of choosing which of many aspects of research and other scholarly output on the topic to include. Not surprisingly, rather than a revision, this book turned out to be at least two-thirds new material. The Contextual Model of Learning is re-introduced in Chapter 1 and continues to underpin much research in museums. For example, Molly Phipps (2010) analyzed 85 articles published during 1997 - 2007 in three key science education journals, and 14 of these articles used Falk and Dierking's (2000) Contextual Model of Learning as their framework. As Falk and Dierking (2013) pointed out

Using this framework to understand the museum experience has proven to be not only an informative way to make sense of the complexities of the museum experience from a visitor's perspective, but also a valid way to empirically measure the interaction and relationship of the numerous factors that contribute to museum visitor behavior and learning. (pp. 26-27)

Like The Museum Experience, the revised version has had enthusiastic reviews. By updating their seminal work, Falk and Dierking have made The Museum Experience Revisited a must read for museum professionals who want to have the greatest impact on their visitors. With new references to social and digital media, insights into visitor motivations and learning, and suggestions for practitioners, it's again among the most influential of resources. (Cynthia Vernon, Vice President of Education and Guest Programs, Monterey Bay Aquarium; http//www.lcoastpress.com/book.php?id=3910

The Museum Experience Revisited will be as powerful a tool for all museums and science centre professionals for the next twenty years as The Museum Experience has been since 1992. It has the fragrance of wisdom and the texture of common sense. I cannot see how anyone in the museum field could possibly survive without reading it. (Per-Edvin Persson, Director of Heureka, The Finnish Science Centre; http://www.lcoastpress.com/book.php?id=391)

Although these three books (Falk and Dierking 1992, 2000, 2013) are aimed at museum professionals and none focuses specifically on learning in science, all three have contributed significantly to the field of science education, particularly learning science in out-of-school 
settings. The first two of these books (Falk and Dierking 1992, 2000) have over 3,000 citations, a very high count for books. The Museum Experience has been translated into Japanese and Chinese, and the contextual model has found use in other countries. Elízabeth Hoyos, Presidenta Ejecutiva at the Corporación Maloka in Columbia, describes its value.

The interactive model about the experience in the museum is the most important reference to understand our Latin American audiences. We have a very successful frame to understand the education dynamics that happens in the museums and to be able to think in new strategies in different directions, from marketing, to design, operation and education programs in our scenarios.

(Elízabeth Hoyos, personal communication March 11, 2014)

Elizabeth continued with a statement of recognition of John and Lynn's work, and the importance of their visit to Colómbia and Maloka in January, 2009.

For us in Maloka it was a great honor and opportunity when we had them here, not only as researchers and wise teachers, but also as honest, loving and committed persons, with whom we enjoyed a wonderful friendship that will last forever. As their students, we really admire their skills as docents, and we perceive them as masters and leaders of the future. (Elízabeth Hoyos, personal communication March 11, 2014)

John and Lynn have been "masters and leaders" in different but complementary ways. Both continue to champion free-choice, life-long learning, together and separately, John, through his work on identity and his cross-institutional impact, and Lynn through her work at the community level with youth and families, all with an equity focus.

\section{John's work: identity and impact}

John's interest in learning and the personal processes of learning have long underpinned his work. In 1997 he published a paper on advances in neurosciences and its implications for visitor studies (Falk 1997), using its findings to impress upon readers the complexity of the learning process and how a much broader view than currently employed was necessary if museums were to better "understand why people go to museums, what they do there, and what they take away 
with them from those experiences" (p. 237). Martin Storksdieck, immediate past Director of the National Academies' Board of Science Education and now the Director of the Center for Research on Lifelong STEM Learning at Oregon State University, described John's fascination with this topic.

Learning as an ontological process that adjusts a (human) being to the everchanging social and environmental context is only a part of a deeper question: understanding what drives us as individuals. Who are we? And who decides? Why do we prefer a certain landscape? John's graduate work was situated in the intersection of ecology and science education, and it raised this seemingly innocuous question. I think the question never left him. He continued to ask the question "but why are we doing this in the first place?" What really drives us to go to a museum, or visit a national park, or watch a NOVA show? There is a connection between landscape preferences and a trip to the art museum, and it lies in our lifelong quest to understand who we are. John's recent work on Self and Identity is simply a logical extension of his previous work, all asking the question why we do what we do, and how this relates to who we are, or think we are, or wished we are. In that sense, as a scholar and simply curious mind, John has made it his passion and career to ask, from a science perspective, the questions that have puzzled us since time immemorial, and have been at the foundation of religion, faith and community. (Martin Storksdieck, personal communication, May 6, 2014)

John developed the ideas of self and identity in trying to understand this process, and he has written extensively about the concept of identity as a means of understanding the visit experience. It was fundamental to what is arguably the most major study investigating the impact of visitors to zoos and aquariums, which was led by John (Falk, Reinhard, Vernon, Bronnenkant, Heimlich, and Deans 2007), and has permeated much of his work over the last decade or so. Perhaps most significant is his 2009 volume which set out this concept in clear terms that resonated with museum professionals.

John's ground-breaking book of 2009, "Identity and the Museum Visitor Experience", which at least for me was one of those mind-boggling 
experiences "finally someone makes sense of it all". John came over to conduct a seminar with my management team to help us rethink our marketing and operational strategies. (Per-Edvin Persson, personal communication, March 22, 2014)

John's ideas have significantly impacted other researchers and their fields, and Per Edvin's reference to "John came over" hints at the enormous impact John has had on others, both through his work, and personally through cross-institutional and international consultancies. Many have led to life-long friendships and enduring partnerships. Roy Ballantyne, a Professor in the Business School (Tourism) at The University of Queensland, described one such partnership.

John is the consummate ideas man and I have enjoyed and shared many hours talking and debating issues with him that relate to cutting edge theory and practice in visitor environmental and museum learning. These discussions have influenced the direction of my academic research and helped our Visitor Research team focus and prioritize our research work in the area of visitor environmental learning and behavior change. Of central importance in this regard, was hearing John's ideas about free-choice learning and reading his and Lynn's book, Learning from Museums (2000) where they proposed and discussed the Contextual Model of Learning. At this time, the area in which I had been researching for most of my academic life, environmental education (both formal and informal), had become "stuck" - going over and over the same things - due to the fact that those trying to work toward changing environmental behavior were at risk of, and often attacked for, being behaviorists or for attempting to indoctrinate school students. John's ideas relating to free-choice learning were able to be used to unblock this impasse how could one be accused of indoctrinating people if you were designing freechoice, environmental learning experiences aimed at facilitating visitor adoption of environmentally sustainable behavior?

Accordingly, over the past 10 years, John has worked with our research team at the University of Queensland (Jan Packer, Karen Hughes, Nigel Bond, Chelsea Forbes and I), on numerous joint research projects that have arguably made, 
and continue to make, a difference to the ways in which eco- and wildlife tourist attractions design their free-choice visitor experiences to maximize the impact on visitors' long-term adoption of environmentally sustainable behavior. (Roy Ballantyne, personal communication, March 10, 2014)

John's ideas and skills in policy and knowing how to get things done have impacted other organizations. He was one of the co-founders and original Co-Principal Investigators of the Center for the Advancement of Informal Science Education (CAISE), established in 2007 with support from the National Science Foundation and housed at the Association of ScienceTechnology Centers (ASTC) in Washington, DC. Its powerful influence might best be summarized by words from its website:

The Center for the Advancement of Informal Science Education (CAISE) works in collaboration with the National Science Foundation (NSF) Advancing Informal STEM Learning (AISL) Program to strengthen and advance the field of professional informal science education and its infrastructure by providing resources for practitioners, researchers, evaluators and STEM-based professionals. CAISE also facilitates conversation, connection and collaboration across the ISE field — including in media (TV, radio, and film), science centers and museums, zoos and aquariums, botanical gardens and nature centers, cyber learning and gaming, and youth, community, and out of school time programs. (http://informalscience.org/about/about-caise)

J. Randy McGinnis, Professor of Science Education at the University of Maryland and Past President of the National Association of Research in Science Teaching (NARST), recalled how when I came to work with John on the NARST Board (2010-2013), he became someone whom I viewed as a passionate advocate of positions he held firmly, and most important from my perspective as President of NARST, a supportive partner in making changes in the association as a way to move it forward.

In one instance, John and I, and several other NARST board members, were invited guests at a National Science Foundation-supported conference in the USA on "Catalyzing Research in Science Education Policy" (the conference 
developers were Nancy Brickhouse, James Earl Davis, and Stephen Norris). For most of us science education researchers at the conference, while we were interested in the notion of policy, policy itself was not an area of our expertise, so we struggled in our attempts to consider how we could interface with policy development beyond our forte of providing research findings to policy makers. Not John, however. He was a maestro at articulating his expertise in policy and how to take meaningful actions not limited to conducting research and reporting findings. His carefully thought out and tested strategies added much to the assembled group's deliberations of bringing policy considerations to the science education research community. I know he certainly educated me in a significant manner in this area, and made me very pleased that on the board that I served as presiding chair he represented our association ("A worldwide organization for improving science teaching and learning through research") so well to outside constituencies as a chair of a policy committee. (J. Randy McGinnis, personal communication, March 26, 2014)

There is no doubt that John is a big-picture thinker. His efforts to push the boundaries and assist other researchers to do the same have advanced our conceptual understanding of freechoice learning and learning in informal contexts in general. As Martin Storksdieck pointed out, "John has been recognized and awarded for his groundbreaking and persistent work on freechoice learning, in part because of his ability to synthesize scholarship from a wide range of disciplines and translate it into accessible language and metaphors" (personal communication, May 6, 2014). John's clever use of metaphor is exemplified in "The Director's Cut", his synthesizing article in the 2004 special issue of Science Education on Museum Learning and Research, edited jointly with Lynn and Kirsten Ellenbogen.

Throughout his career, John has attempted to frame learning more holistically, both in time and space and he has consistently pushed others to try to think this way as well. According to John, learning always involves myriad variables that influence learning across multiple time and spatial scales. This was the thrust of his argument in "The Director's Cut" (Falk 2004). While John has taken this holistic view, and focused on the psychologically-based self and identity work, Lynn has utilized a bottom-up perspective that focuses on learners and attempts to 
understand more deeply the ecology of their learning from their own perspectives, particularly highlighting the sociocultural dimensions of learning and identity and how they impact learner engagement, a complementary perspective, as we see in the next section.

\section{Lynn's work: community, youth, family, and equity}

As seen from the perspective of one of her students, Lynn's work draws 'from a variety of sociocultural perspectives, her research and writings have explored family-based learning, learning conversations and discourse, and the cultural and historical contexts that afford and constrain learning, such as race, gender, institutions, poverty, and more" (Scott Pattison, personal communication, March 17, 2014). Her underpinning focus is on life-long, free-choice, out-ofschool time learning, and she works passionately and untiringly, as revealed in this anecdote from Dale McCreedy, Director, Gender and Family Learning Programs at the Franklin Institute Science Museum.

I walked into the hotel bar, looking to meet my colleague Lynn Dierking. If anyone else had been there ahead of me, I might have expected to find them sitting at a table with a drink or phone or computer. However, not Lynn! She had fully engaged the bartender, was discussing issues of informal learning and was promising follow-up emails in the future. Ever an advocate for informal learning and a people person like few others! (Dale McCreedy, personal communication, September 5, 2014)

But Lynn's passion does not preclude quality research. According to Ken Tobin, Professor at City University New York, "her work is notable because it explores facets of science education that are outside of the mainstream, using frameworks to theorize teaching and learning of science and research methods in ways that promote innovation and transformation" (personal communication, March 15, 2014). This is beautifully illustrated in the recently completed Cascading Influences: Long-term Impacts of Informal STEM Experiences for Girls published by The Franklin Institute (McCreedy and Dierking 2013). This publication reports the findings from an NSF-funded retrospective study of the long-term impacts of gender-focused free-choice learning programs on 175 young women's lives, some 5-25+ years after their experience. The study probed these women's interests, engagement, and continued involvement in science, in 
terms of both their careers and leisure pursuits. The notion of broadly defining impacts, both in terms of undertaking further STEM education and/or entering careers, as well as recognizing how these experiences influence lifelong STEM hobbies and pursuits, was a contribution that Lynn brought to this study from the start, as well as to the field as a whole, influencing publications like the National Research Council's consensus study on Learning Science in Informal Environments: People, Places and Pursuits (National Research Council 2009) and the accompanying practitioner volume, Surrounded by Science (Fenichel and Schweingruber 2010). In Dale's view,

Lynn's desire to embrace multiple perspectives was apparent in her advocating for a convening prior to the completion of the Cascading Influences report. Inviting colleagues from a range of backgrounds to critique the findings was a wonderful indicator of her openness to critical reflection, and commitment to the value that comes from thoughtful and important collegial push and pull. The convening ultimately allowed us to draw upon diverse areas of expertise within an environment of mutual respect among colleagues who cared deeply about girls and women, especially in science. (Dale McCreedy, personal communication, September 5, 2014)

Finding participants and choosing credible means to measure impact are just two of the challenges that make retrospective studies such as these logistic nightmares. Innovatively, Dale and Lynn drew on a "community of practice" theoretical framework and completed a study of value to both practitioners and researchers, with recommendations for STEM educators and reflective lessons on the research process. The ability to reflect on what one does, and to learn from it is a skill Lynn has in abundance, and it pervades her work. Scott Pattison, one of Lynn's doctoral students, explained:

Ever since I've known Lynn, she has advocated that STEM educators and researchers continuously reflect on their own assumptions and the ways that social, cultural, and historical contexts shape not only how learning happens but the very goals that we strive for as STEM educators. 
If there is one thing that Lynn is sure to bring up at any project meeting, it's the importance of understanding the world from the learner's perspective. Unlike educational researchers, learners don't compartmentalize their lives neatly into specific topics, settings, or outcomes. Instead, they cross freely between school, work, and life, building meaning in unique but personally relevant ways according to their own goals, circumstances, and pathways. Although Lynn is often known for her work in museums, much of her research has taken a much broader perspective, looking at how individuals and families learn across settings and over time and how communities and institutions can best understand and support these complex ecosystems of learning. (Scott Pattison, personal communication, March 17, 2014)

Jrene Rahm, Professor at the Université de Montréal, illuminates Scott's last comment:

Like many others, I always thought of Lynn as a science museum researcher who has been involved in so many key studies that marked the field and has contributed so many articles and books to the advancement of the field. However, a while back, maybe eight years, when I was looking for literature on science learning in afterschool programs, I stumbled on a very interesting position paper by Lynn that she was asked to write by the Coalition of Science Afterschool (CSAS), in which she tried to address the link between engagement in afterschool science programs and STEM learning and called it "Linking afterschool programs and STEM learning: a view from another window." The perspective she offered was very rich and "another window" in many ways to the discourse at the time about afterschool programs that were supposed to fix the STEM pipeline problem. As if life were that simple! She argued well that OST settings are important but part of a complex network of activities and practices that constitute science literacy development. She also hinted at life-long learning and her long passion and advocacy for new more global or systemic perspectives on learning and in many ways talked about lifelong, life-wide, life-deep learning before it was part of another report. In that position paper, she also referred to issues of access to quality OST 
programming and hinted at problems of equity. That's another important dimension of Lynn's work, her concern for equity in informal science education as her recent work with girls in afterschool programs and the tracking of long-term impacts of informal STEM on girls-women also attests to [McCreedy \& Dierking, 2013] (Jrene Rahm, personal communication, March 29, 2014)

Ken Tobin had another insightful comment about Lynn's contribution:

An impressive feature of her way of being a science educator is her collaborative style that exemplifies high levels of compassion and attentive listening as well as forthright speaking in ways that are emphatic while not being pushy. It is not surprising that Lynn has been successful in collaborating with others to expand the quantity and quality of research on free-choice learning. (Ken Tobin, personal communication, March 15, 2014)

Lynn's outgoing and supportive nature has developed enduring friendships and productive partnerships. Dale McCreedy explained how, in the mid-90s, after

a fortuitous ride to the airport with John after an Advisory board meeting for Project Astro, I was introduced to Lynn, the Institute for Learning Innovation, and her aligned interests. Since that time, Lynn has been not only a colleague but also a critical friend to me professionally, and a true friend to me personally. Her commitment to me and to others in the field has been evident in her support of dissertation work (mine included) and various other professional efforts. Indeed, when The Franklin Institute staff, immersed in various museum studies or education programs, hear that Lynn is in the building, I have witnessed them interrupting our meetings to introduce themselves and share what an impact John's and Lynn's work has had on them personally and professionally.

In thinking about Lynn and John together as both academic colleagues and lifelong friends, it is apparent that their different - almost opposite - styles are a great asset that has led to them being a strong and influential team - an 
intellectual force more impactful than either could muster on their own. This, together with their kindness, forthrightness and passion will be long-felt.

Together they have had an enormous impact on the field. (Dale McCreedy, personal communication, September 5, 2014)

This final comment from Dale signals a return to the joint effort of Lynn and John to build the field of science education through free-choice learning.

\section{Building the field of science education and free-choice learning}

The establishment of the Institute for Learning Innovation in 1986 marked the beginning of an era which recognized the importance of free-choice learning and soon research began to grow exponentially. The Institute became both a pioneer in, and a very significant contributor to research in this field, with John as Director and Lynn as Associate Director overseeing more than 200 research and evaluation projects across a wide range of free-choice learning institutions. Equally importantly, it nurtured a team of researchers, many of whom have moved on to leading roles in other free-choice learning environments. One of these was Martin Storksdieck, who reflected on the impact of the Institute.

The non-profit Institute for Learning Innovation that John founded and directed for more than 20 years became an important institution of applied scholarship. Conducting research and evaluations in museums, zoos, aquaria, parks and similar, built learning and "experience" environments in which people engage with the natural and cultural world, John and a growing team of researchers (me included) helped with empirical evidence, practitioners who had a need for feedback and validation of their work, particularly when they pushed boundaries and explored new avenues; but we would also uses evaluation to advance scholarship. And because John is a Big Picture thinker, the scholarship would not be limited to understanding what was conducive to learning (or whether any one exhibit or program worked as intended); John and Lynn pushed our concept of how and where learning occurred by championing the term "free-choice learning" (as a positive moniker) over the term "informal learning" (as a moniker that conveys something is missing). John and Lynn 
were right to insist that language matters, and were correct to insist that we should optimize our work in two complementary directions: supporting the immediate with empirical research based on conceptual scholarship, and shaping our overall understanding of the field by advancing the conceptual scholarship itself. (Martin Storksdieck, personal communication, May 6, 2014)

One of the strategies employed by the Institute to advance the field of free-choice learning was to seek funding from the National Science Foundation and other sources to bring together prominent people who were able to discuss invited papers and synthesize the outcomes of discussion into edited books. The first of these was Public Institutions for Personal Learning: Understanding the Long-Term Impact of Museums (Falk and Dierking 1995), a volume which stimulated almost a generation of doctoral and other researchers (including me) to improve their research knowledge and understanding of the field. Another insightful volume was Free-Choice Science Education: How We Learn Science Outside of School (Falk 2001), which brought together researchers, policy makers, and leading practitioners to discuss the strengths, weaknesses, and benefits of building a better national infrastructure for free-choice learning. Preparations for the next book, In Principle - In Practice: Museums as Learning Institutions (Falk, Dierking and Foutz 2007), included a preconference special issue of Science Education (July 2004, Volume 88, Supplement 1), articles from which were rewritten after discussion and critique at the conference to form part of the book. These were accompanied by a number of other jointly written papers that consolidated and synthesized research findings and discussion outcomes to improve current practices and identify avenues for further research.

Both John and Lynn have devoted their working lives to promoting learning, emphasizing that learning is a continuous, cumulative process that happens throughout our lives and that there are opportunities for learning in everything we do. Apart from their considerable research output, they also have worked to communicate their ideas beyond the academy. Their easy-to-read book, Lessons without Limit: How Free-Choice Learning is Transforming Education (Falk and Dierking 2002), illustrates how we learn over our entire life-time. It is impossible to read this book without gaining a sense of warm and friendly, family-loving people, right from page 1 where a delightful anecdote introduced the three Falk children learning about the Civil War on location at the Antietam National Battlefield. "As a family we were committed to learning", 
wrote John and Lynn, “And learn we did” (p. 2). The innovative "Free-Choice Learner's Bill of Rights" (Falk and Dierking 2002, p. 134) sets out the rights that people have to become and remain life-long learners. This may sound a little distant from science education, but it is not. Learning throughout our lives (except perhaps when we are at school) is multidisciplinary; science is intertwined, almost seamlessly, with mathematics and geography and art and so on. The Contextual Model of Learning (which also underpins Lessons without Limit) is about learning all of the things that we might encounter in any learning opportunity, and that includes science.

There was a significant increase in research in the field of free-choice learning during the last two decades of the $20^{\text {th }}$ century, but as alluded to earlier, there remained considerable confusion about terminology, in particular, the term "informal learning. It was clear that research in science education needed to include more than just the experiences of schooling, but there needed to be clarity around the idea of learning outside of school. Lynn and John acted constructively, and inclusively. They persuaded the Board of the National Association of Research in Science Teaching (NARST) to establish an Informal Science Education Ad Hoc Committee. This Committee, co-chaired by Lynn and John, was tasked to focus on the organization's positioning in regard to informal science education. The NARST Board accepted the Committee's proposed policy statement (Dierking, Falk, Rennie, Ellenbogen, and Anderson 2003) and it was published in a special issue of the Journal of Research in Science Teaching on Informal Education (Feher and Rennie 2003). The policy statement was a boost to the field. Not only did it define more broadly this area of research to include a variety of out-of-school environments, it assisted NARST in taking a leading role in building a community of researchers and facilitating opportunities for collaboration with other research areas in NARST. As pointed out by Dierking et al. (2003), the term "has significant limitations because it artificially delimits efforts to describe the type of real world learning that humans engage in daily: learning that occurs across broad spatial and temporal contexts, both inside and outside of schooling" (p. 108). Strand 6 in the NARST conference program, born from this initiative, continues to grow in strength, and 11 years later, another special issue of the Journal of Research in Science Teaching, co-edited by Lynn and Tali Tal was published (Tal and Dierking 2014). This special issue has a theme of learning science in out-of-school, everyday situations other than museums, a theme which, as Tali Tal explained, "allowed us to discuss some of the more recent 
developments in the field of learning science in everyday life" (personal communication, October 1, 2014). Lynn and John also were the founding, and until recently, co-editors of the special Learning Science in Everyday Life section of the journal Science Education which for more than a decade has represented a major vehicle for disseminating scholarly research in the area of lifelong, free-choice science learning.

One of the overarching problems in research relating to learning from informal educational institutions like museums is measuring impact. Increasingly, the measurement of impact has significant economic implications because so many of these institutions rely on public funding and are therefore subject to pressure to demonstrate accountability. Three decades ago, Falk, Koran, and Dierking (1986) wrote "unfortunately, because of the unstructured nature of learning, museums never know with certainty what impact they have on the publics they serve" (p. 507). John and Lynn have been at the forefront of several initiatives to try to find answers to this problem using ideas that resonate well with the Directors of such institutions. Per-Edvin Persson explains:

John and Lynn are very special researchers, as they have focused their research on issues that are of prime importance to the development of the field, and that are important from a Director's point of view, as well. They have done research that is directly applicable to the everyday life of an institution. A rare compliment to academic researchers, methinks.

[One] piece of work that I think [is] particularly important . . is the article by John H. Falk, Carol Scott, Lynn D. Dierking, Leonie Rennie and Mika Cohen Jones, published in 2004 and entitled "Interactives and visitor learning" (Curator, 47, 171-198). I personally think this is one of the most significant papers ever published in the museum or science center field, as it shows that science centers have measurable long-term effects related to appreciation and understanding of science. This was the first piece of evidence showing it clearly, and I still remember that I made my Board read the article right away (well, at least I provided them copies and a strong suggestion). (Per-Edvin Persson, personal communication, March 22, 2014) 
Much more recently, John and Lynn have been leaders of an international project to measure the impact of science centers. Per-Edvin relates how this came about.

John led a very important cooperative study in 2013-14, the International Science Centre Impact Study, with 17 participating science centers from 13 countries. The report was published in February 2014. The whole effort started from a conversation John and I had in September 2011 in Cape Town, at the 6th Science Centre World Conference. He said he thought he could prove that success in the formal education system is related to science centers, to which I retorted "then we have to do it". I managed to persuade enough of my colleagues to collect the money needed, and off he went to produce the research and to prove what he intended to. (Per-Edvin Persson, personal communication, March 22, 2014)

Elizabeth Hoyas explained the importance of this study:

The empiric evidence lets us understand the correlations between visiting an interactive science center, and the interest, knowledge, understanding and identity with science and technology of the visitor. This is a valuable project not only to prove the importance of the interactive science centers in the society, but to give us excellent new tools to understand much better what we do and to improve our processes. Now, we are much more conscious of the responsibility and opportunity to keep developing our field, implementing innovation in our practices, and the importance of evaluation to keep learning and growing to serve our communities much better. (Elízabeth Hoyos, personal communication March 11, 2014)

In 2006, John and Lynn moved from Annapolis and the Institute (although still retaining links, John as President Emeritus and Lynn as Vice President for Special Initiatives) to Oregon State University (OSU), to share the full-time tenured position of Sea Grant Professor of FreeChoice STEM Learning. This move into the academy was an effort to foster the next generation of learning leaders that understand lifelong STEM learning, in particular, the free-choice learning field. At OSU they have helped to create the first Master's and Doctoral programs in the world 
focused solely on free-choice learning, in the process assisting to transform the College of Science's, and ultimately the College of Education's education programs from a focus on formal education to one focused on learning across the entire lifespan. In this way, all of OSU has become aware of and supportive of free-choice learning. Their move to a more formal academic role was new to neither John nor Lynn, as Lynn had been a tenure track faculty member and both had held visiting and/or honorary roles at several universities. Being half-time professors at OSU allowed them to continue to work on grants and undertake consulting, nationally and internationally, thus continuing to spread knowledge and understanding through their research in free-choice learning. Scott Pattison, a doctoral student at Oregon State University, explains

My first introduction to the theoretical and empirical foundations of the field of free-choice STEM learning was through John and Lynn's seminal works.

These publications have defined and shaped the academic and professional discourse in this field for over three decades and have helped to organize a disparate group of researchers and educators into a more coherent field of professionals. Like so many of us, John and Lynn's books helped me see my work as part of a larger whole and inspired me to question my educational goals and seek evidence for the approaches underlying my work. Together, Lynn and John created one of the most influential frameworks for understanding free-choice STEM learning. Their contextual model helped to put "learning" front and center in our work and connected free-choice learning to the other major disciplines of social science, including education, sociology, and psychology. (Scott Pattison, personal communication, March 17, 2014)

Not only is free-choice learning connected to other disciplines, as Scott pointed out, it occurs in a "learning landscape" that includes, beyond formal and informal educational institutions, the various media, libraries and other community-based resources and people's hobby groups and workplaces. John and Lynn have suggested that future research should include not only this learning landscape, but "an ecology of learning for life" (Falk and Dierking 2012, p. 1074). For adults, particularly, there are so many offerings that "compete in the leisure marketplace; all are attempting to put the learner's needs and interests first. This changed learning landscape makes historical top-down models of science learning research as obsolete as the institutions sponsoring 
them" (p. 1075). Also obsolete, John and Lynn suggest, are narrow notions of learning conceptualized in academic contexts. Instead, they argue, "we need a more learner-centered approach to science education research that places issues of learner motivation and identity at the center of inquiry" (p. 1075). This enables us

to situate the learner at the center rather than the periphery of the learning process; as an active co-contributor, not merely a passive recipient. In order to meaningfully understand what learning is but even more importantly, why it happens, studies also should frame learning within the larger ecological context of an individual's life and the learning landscape in which he or she participates. (Falk and Dierking 2012, p. 1076)

They also have continued efforts at OSU that they had initiated earlier through the Institute. For example, in August 2009, they hosted a National Science Foundation-funded international invitational conference, 2020 Vision. The meeting was specifically designed to examine the opportunities, challenges, and barriers to developing cross-cutting research questions and paradigms that integrate better understandings of learning as a personally constructed, life-long process of making meaning, as well as to propose a range of new visions for possible future research directions. Researchers investigating $\mathrm{K}-12$, collegiate teaching and free-choice learning were invited to participate; this issue represents the culmination of that effort.

John and Lynn do not merely argue for these more holistic approaches to research; they demonstrate them. Together, in April 2013, they delivered an Education \& Human Resources Distinguished Lecture at the U.S. National Science Foundation, an honor in recognition of their leadership within the STEM education field. This lecture provided an overview of their recent contributions to the field, with Lynn first detailing thinking about where, when, how, why, and with whom learning happens and focusing on the bottom-up perspective, efforts to deeply understand learning and learning ecologies from learners' own perspectives. Lynn illustrated her theme from the NSF Cascading Influences project, completed with Dale McCreedy (McCreedy and Dierking 2013) and described earlier. In the second part of this presentation, John talked about the top-down view that focuses on understanding the structure and functioning of existing, as well as potential, interrelationships between actors and agents in a broad learning landscape, using findings from his longitudinal study of the contribution of science learning resources in 
Los Angeles (Falk and Needham 2013) and review of the science education community in the United Kingdom (Falk, Dierking, Osborne, Wenger, Dawson and Wong in press).

\section{A final note}

John Falk and Lynn Dierking have published together for three decades, so it is not surprising that their names are often mentioned together, and sometimes it is easy to think of them as one. However, as is often the case with people working well together, the sum is more than the parts. They work jointly in complementary ways, but also separately, making significant and valued contributions to both research and practice. John and Lynn were both named to the Centennial Honor Roll of the American Association of Museums, as members of the 100 most influential individuals in the museum community, 1906-2006, and both were recipients in 2010 of the John Cotton Dana Award for Leadership from the American Association of Museums, the highest honor bestowed on persons outside the museum field who exhibit outstanding leadership and promote the educational responsibility and capacity of museums. These honors, and the contents of their leadership presentation described above, emphasize that John and Lynn are about quality learning, particularly in STEM, both free choice as it happens in institutions like museums but also in other out-of-school situations, for the whole of life. Jrene Rahm describes this commitment to a quality education for all (one that she shares), a commitment

that everybody on this planet should have access to quality opportunities to engage with science and have fun with it. ... something we tend to forget, that most of us do engage with science in genuine ways and ways that mark us for life, yet such ways are not necessarily recognized by the system or sometimes not even by us as doing science. Yet, they are part of life-long learning and our identity or who we are and are becoming, while they also attest to our creativity and potential as learners and actions that may one day make for a revolution of the learning landscape! (Jrene Rahm, personal communication, March 29, 2014)

John and Lynn continue as Sea Grant Professors at OSU. Lynn is also currently Associate Dean for Research in the College of Education. In 2012, John founded and was initial Director of the university-wide Center for Research on Lifelong STEM Learning. This Center recognizes the 
multiple STEM-related issues faced in the current century and has a mission to help individuals become life-long STEM learners and practitioners across all settings through applied research and evaluation geared at answering questions that emerge from practice and policy. Through both free-choice learning and discipline-based education research, the Center "works to advance these capacities by initiating new, foundational lines of research, coordinating existing activities across disciplines, curricular levels and research areas and by providing a forum for the crosspollination of ideas with a wider-base of expertise to address cross-cutting STEM-learningrelated challenges" (http:/stem. science.oregonstate.edu/). Both John and Lynn are affiliate researchers in the Center and continue to actively engage in research, collectively and individually, serving as principal or co-principal investigators on several major grants relating to free-choice STEM learning. John also serves on the Center's National Advisory Board. In 2014, John, Lynn and a colleague in Portland reincorporated the Institute for Learning Innovation in Oregon. It had closed its doors in Maryland in 2012, and the re-opening was endorsed by the former board of directors. In this re-invention, its mission has been redefined as the role that lifelong, life-wide and life-deep learning, in particular free-choice learning, can play in helping to address critical issues facing the world. At the time of writing, three areas of focus have been identified: (1) The environment and sustainability; (2) health and well-being; and, (3) equity and public value. This promises to be another significant support to the field of life-long learning particularly as it relates to STEM education.

As I close this article, I am reminded of a very warm night in Canberra, Australia in February 2002. The 3rd Science Centre World Congress held its Conference Dinner in the Great Hall of Australia's Parliament House. There, long after people like me had retired, exhausted, John and Lynn remained dancing together with amazing energy. I hope they continue to dance together for a very long time, and we researchers will continue to reap the benefits of their incredible contribution to the field of free-choice learning, especially in science.

\section{References}

Bamberger, Y., \& Tal, T. (2007). Learning in a personal context: Levels of choice in a free choice learning environment in science and natural history museums. Science Education, 91(1), 75-95. DOI: $10.1002 / \mathrm{sce} .20174$ 
Dierking, L. D. (2007). Understanding the nature of science learning. In K. Tobin \& W-M. Roth (Eds.), The culture of science education: Its history in person (pp. 239-250). Rotterdam, The Netherlands: Sense Publishers.

Dierking, L. D., Falk, J. H., Rennie, L., Anderson, D., \& Ellenbogen, K. (2003). Polic y statement of the "Informal Science Education" Ad Hoc Committee. Journal of Research in Science Teaching, 40(2), 108-111. DOI 10.1002/tea.10066

Falk J. H. (1971). Guarding your thermometers. American Biology Teacher, 33(5), 295-296. DOI: $10.2307 / 4443471$

Falk, J.H. (1974). Estimating experimenter induced bias in field studies: A cautionary tale. Oikos 25, 374-378. DOI: 10.2307/3543959

Falk, J. H. (1976). Energetics of a suburban lawn ecosystem. Ecology, 57(1), 141-150. DOI: $10.2307 / 1936405$

Falk, J. H. (1983). Time and behavior as predictors of learning. Science Education, 67(2), 267-276. DOI: $10.1002 /$ sce.3730670214

Falk, J. H. (1997). Recent advances in the neurosciences: Implications for visitor studies. In M. Wells \& R. Loomis (Eds.), Visitor Studies: Theory, Research and Practice (vol. 9, pp. 227238). Jacksonville, AL: Visitor Studies Association.

Falk, J. H. (Ed.). (2001). Free-choice science education: How we learn science outside of school. New York, NY: Teacher's College Press, Columbia University.

Falk, J. H. (2004). The director's cut: Towards an improved understanding of learning from museums. Science Education, 88, S83-S96. DOI: 10.1002/sce.20014

Falk, J. H. (2009). Identity and the museum visitor experience. Walnut Creek, CA: Left Coast Press.

Falk, J. H., \& Balling, J. D. (1982). The field trip milieu: Learning and behavior as a function of contextual events. Journal of Educational Research, 76, 22-28. 
Falk, J. H., \& Dierking, L. D. (1992). The museum experience. Washington, DC: Whalesback Books.

Falk, J. H., \& Dierking, L. D. (Ed.). (1995). Public institutions for personal learning: Establishing a researchagenda. Washington, DC: American Association of Museums.

Falk, J. H., \& Dierking, L. D. (2000)._Learning from museums: Visitor experiences and the making of meaning. Walnut Creek, CA: AltaMira Press.

Falk, J. H., \& Dierking, L. D. (2002). Lessons without limit: How free-choice learning is transforming education. Lanham, MD: AltaMira Press.

Falk, J. H., \& Dierking, L. D. (2012). Lifelong science learning for adults: The role of freechoice experiences. In B. J. Fraser, K. Tobin, \& C. McRobbie (Eds.), Second International Handbook of Science Education (Vol. 2, pp. 1063-1079). Dordrecht, The Netherlands: Springer. DOI: 10.1007/978-1-4020-9041-7_70

Falk, J. H., \& Dierking, L. D. (2013). The museum experience revisited. Walnut Creek, CA: Left Coast Press.

Falk, J. H., Dierking, L. D., \& Foutz, S. (Eds.). (2007). In principle, In practice: Museums as learning institutions. Lanham, MD: AltaMira Press.

Falk, J.H., Dierking, L.D., Osborne, J., Wenger, M., Dawson, E. \& Wong, B. (in press $\underline{2015}$ ). Analyzing science education in the U.K.: Taking a system-wide approach. Science Education, 99(1), 145-173.- DOI: $10.1002 /$ sce. 21140

Falk, J. H., Koran, J. J. Jr., \& Dierking, L. D. (1986) The things of science: Assessing the learning potential of science museums. Science Education. 70, 503-508. DOI: $10.1002 /$ sce. 3730700504

Falk, J. H., Koran, J. J. Jr., Dierking, L. D \& Dreblow, L. (1985) Predicting visitor behavior. Curator, 28(4), 326-332. DOI: 10.1111/j.2151-6952.1985.tb01753.x 
Falk, J. H., Martin, W. W., \& Balling, J. D. (1978). The novel field trip phenomenon: Adjustment to novel settings interferes with task learning. Journal of Research in Science Teaching, 15, 127-134. DOI: 10.1002/tea.3660150207

Falk, J. H., \& Needham, M. D. (2013). Factors contributing to adult knowledge of science and technology. Journal of Research in Science Teaching, 50(4), 431-452. DOI: 10.1002/tea.21080

Falk, J. H., Reinhard, E. M., Vernon, C. L., Bronnenkant, K., Heimlich, J. E., \& Deans, N. L. (2007). Why zoos \& aquariums matter: Assessing the impact of a visit. Silver Spring, MD: Association of Zoos \& Aquariums.

Falk, J. H., Scott, C., Dierking, L., Rennie, L., \& Jones, M. C. (2004). Interactives and visitor learning. Curator, 47, 171-198. DOI: 10.1111/j.2151-6952.2004.tb00116.x

Falk, J. H., \& Storksdieck, M. (2005). Using the contextual model of learning to understand visitor learning from a science center exhibition. Science Education, 89, 744-778. DOI: $10.1002 /$ sce. 20078

Fenichel, M., \& Schweingruber, H. A. (2010). Surrounded by science: Learning science in informal environments. Washington DC: The National Academies Press

Koran, J. J. Jr., \& Dierking-Shafer L. (19811982). Learning science in informal settings outside the classroom. In M.B. Rowe (Ed.), Science in the 80's (pp. 52-62). Washington, D.C.: National Education Association. (ERIC Document Reproduction Service No. ED 218 096)

Koran, J. J., Jr., Longino, S. J., \& Shafer, L. D. (1983). A framework for conceptualizing research in natural history museums and science centers. Journal of Research in Science Teaching, 20(4): 325-339. DOI: 10.1002/tea.3660200407

McCreedy, D., \& Dierking, L. D. (2013). Cascading influences: Long-term impacts of informal STEM programs for girls. Philadelphia, PA: Franklin Institute Science Museum Press.

National Research Council. (2009). Learning science in informal environments: People, places, and pursuits. Washington DC: The National Academies Press. 
Phipps, M. (2010). Research trends and findings from a decade (1997-2007) of research on informal science education and free-choice science learning, Visitor Studies, 13(1), 3-22.

DOI.org/10.1080/10645571003618717

Rennie, L. J., \& Feher, E. (Eds.). (2003). Informal education. [Special Issue]. Journal of Research in Science Teaching, 40(2), 105-256.

Tal, T., \& Dierking, L. D. (Eds.). (2014). Science learning in everyday life. [Special Issue]. Journal of Research in Science Teaching 50(3), 251-406.

Biographical information

Léonie J. Rennie is Emeritus Professor of Science and Technology Education at Curtin University. Her research focuses on the learning of science and technology in settings outside of school, and in school community projects. A recent book, co-authored with Grady Venville and John Wallace is entitled Knowledge that counts in a global community (Routledge). 